\title{
Opportunity of Mechanized Harvesting Methods of Cereal Crops in India: A Review
}

\author{
Suryakanta Khandai ${ }^{\text {* }}$, Nitesh Gupta ${ }^{2}$, Saurajyoti Baishya ${ }^{1}$, \\ Kanwar Singh $^{1}$ and Virendar Kumar ${ }^{1}$ \\ ${ }^{1}$ International Rice Research Institute, Assam, India \\ ${ }^{2}$ Assam Agricultural University, Jorhat, India \\ *Corresponding author
}

\section{A B S T R A C T}

\section{Keywords}

Harvest, Drudgery, Time saving, Reduction in losses, Cost of harvest, Paddy

\section{Article Info}

\section{Accepted:}

20 December 2020

Available Online:

10 January 2021
During harvesting, rain, hail and storm often cause considerable damage to standing cereal crops. Rapid harvest facilitates extra days for land preparation and earlier planting of the next crop. The availability and cost of labor during harvesting is a serious problem. The shortage of labour during harvesting season and vagaries of the weather cause great losses to the farmers. It is therefore, essential to adopt the mechanized harvesting methods so that the timely harvesting could be ensured. The use of mechanical devices for harvesting has increased in the recent years. The use of harvesting machines helps in harvesting the crop at proper stage of maturity, and also reduces human drudgery and operational time. This, in turn, generates spare time for education, social, cultural and political activities, and human development especially in women-headed farming households. The mechanical harvesting would be feasible and economical compared to traditional method in terms of time, labour requirement and money. In this paper, the studies on different types of harvesting machines and techniques have been reviewed and analyzed. The data revealed from different studies showed that up to $85 \%$ saving in labor, and approximately $75 \%$ reduction in harvesting losses are possible through mechanized harvesting methods. Besides, the cost of harvesting of paddy was reduced by $55 \%$ per hectare.

\section{Introduction}

It is well known that farm mechanization in the agriculture is an essential input with the potential to transform the lives and economies of millions of rural families. In developing countries with small farms, low productivity, and widespread poverty, mechanization is particularly important to decrease the cost of production, improve farm efficiency, reduce drudgery, improve crop productivity, intensify cropping and increase farm income. Rice is one of the most important staple foods of millions of people, grown in many countries of the world. The total area planted under rice crop in India is 44.5 million ha, which is the largest in the world as against the total area of 166.1 million ha(FAOSTAT data 2018). Production of rice is increasing, but in most parts of the country the poor post- 
harvest management practices impacted quantitative as well as qualitative losses. Currently, India's level of mechanisation is at $40 \%$ compared to $90 \%$ across the developed nations yet harvesting of rice $(70 \%)$ and wheat $(80 \%)$ are highly mechanised $(\mathrm{PwC}$, 2019). Manual harvesting, which is most common in some parts of India, is estimated to consume about $25 \%$ of the total labour requirement of the crop. Depending upon the crop yield, 120 to 250 man-hours are required for cutting, bundling and on-farm stacking of one hectare of paddy field by using traditional sickle (Nadeem, 1983). Labour scarcity during peak period of harvesting leads to delay in harvesting and losses of grain in the field. Also, high labour wages during peak harvesting period adds to cost of cultivation. Considering the above-mentioned problem, mechanized method of harvesting may be the better option. Use of scale appropriate machines have an impact on food security through cost and time saving and reducing harvest and post-harvest losses. A study in Bangladesh identifies cost saving of $37 \%$ and $52 \%$ for using rice reaper and mini-combine harvester over manual operations (Alam et al., 2017).

Harvesting is the operation of cutting/picking/ plucking, digging or a combination of these operations for removing the crop from above or under the ground or removing the useful part or fruits / vegetables from plants. In this paper we are mainly focusing paddy harvesting which means cutting of paddy just above the ground. At harvest the quality of rice is the best, and thereafter deteriorates quickly due to poor harvest and post-harvest practices, such as -

Heat buildup from mold and insect development

Discoloration/yellowing from heat build-up
Cracking from re-wetting of dried grains

Loss of vigor

Reduced head-rice yield

Shattering losses

With the ever-increasing population of India, there is huge increment in food, vegetable and fruit demand with increased consumption, calling for the need of farm mechanization. Mechanized agriculture is the process of using agricultural machinery to accomplish the work of agriculture, greatly increasing farm worker productivity. Farm mechanization reduces the cost of different agricultural operations and offers an alternative solution to tackle the abovementioned problems. Large machineries provide more operations in less time, but they are very costly and beyond the reach of the small and marginal farmers constituting the majority of the farming community in India $(86 \%)$, as well as at global level $(84 \%)$, so manually operated machineries/ equipment are the right choice and common in use. As a step towards mechanization of the harvesting operation for cereal crops, the alternatives available were considered such as manual reaper, self-propelled reaper and binder machine, and the modern technology using combine harvester. Reapers are used for harvesting of crops mostly at ground level, and nowadays the height adjustable reapers are available which could harvest the crops at desired statures. Reapers are classified based on conveying of crops and provision of straw which is considered as economic by-product for animal feed and/or industrial applications. Analternative straw-handling and disposal technology needs to be developed and promoted where farmers have adopted combines for harvesting, as burning of straws is creating environmental pollution and farmers are losing valuable animal feed 
material. Mechanized harvesting can be done by four actions:

Slicing action with a sharp tool.

Tearing action with a rough serrated edge

High velocity single element impact with sharp or dull edge.

Two-element scissor type action.

\section{Goals of good harvesting is to}

Maximize grain yield (minimize losses)

Minimize grain damage

Minimize quality deterioration

Keeping these points in view, work was reviewed to find out improved mechanized methods for harvesting of cereals with the evidence of some important parameters such as effective field capacity, time taken, labor requirement, harvesting losses and cost of operations.

\section{Traditional harvesting technique}

In India, most of the farmers still adopt manual harvesting method for reaping paddy. During manual harvesting process, they are mostly using sickle having serrated type or regular type of blades. Mostly serrated type sickles are used for harvesting paddy and wheat. Scientists in different regions studied the performance of sickle along with the difficulties in traditional method of harvesting. In this paper, we have attempted to compile the results of all relevant studies on these aspects.

Harvesting of field crops is generally done manually with the help of sickle. The shape and size of the sickles vary with the region. It was found that a sickle with serrated surface gave better performance than a plain one with shearing force at the cutting edge (Singh and Singh, 1978). Devnani and Pandey (1981) evaluated the field performance of the newly designed sickle having the size of $255 \mathrm{~mm}$, made from $1.27 \mathrm{~mm}$ thick carbon steel, having elliptical shaped blade with eccentricity of 0.7 , compared tolocal sickle. The blade was riveted to the reinforcing strip, which in turn was riveted to the handle. The result showed that the performance of the improved sickles was better as compared to other sickles. The improved sickle with serrated edge reduced drudgery of farm women by about $16.5 \%$ as compared to local sickle for harvesting wheat crop(Gite and Agarwal, 2000). The comparison of performance of Naveen and Vaibhav sickles with the local sickles for harvesting paddy crop with 12 farm women, showed that their respective output was 47.3, 60.7 and 65.4 $\mathrm{m}^{2} / \mathrm{h}$, with corresponding mean rate of heartbeat/min at 103, 107 and 106, respectively while working in operation using these sickles. The workload was under acceptable limit for day-long work with normal rest pause for the studied sickles (Singh et al., 2012). Another study involving twenty volunteer non-pregnant farm women using serrated and non-serrated sickles showed that the total cardiac cost of work was 290 beats, the physiological cost of work was 7.45 beats/min, the average working heart rate was 115 beats/min and the average energy expenditure was $8.26 \mathrm{KJ} / \mathrm{min}$ during the harvesting activity performed by improved tool, the Naveen serrated sickle. It was found that the improved tool was ergonomically good and women-friendly, that reduced drudgery and thus was helpful in improving the efficiency of women (Verma et al., 2016). A study was conducted to determine the physical fitness, time and activity profile and physiological stress of farm women during wheat harvesting activity. The results revealed that $19.5 \%$ of working efficiency is increased by using serrated sickle, as an average one farm woman harvested 50 bundles of wheat by using serrated sickle while only 39 bundles of wheat were 
harvested through local sickle, and using serrated sickle, with average working heart rate of women to be 110 beats/min. Similarly, energy expenditure was found to be $12 \mathrm{~kJ} / \mathrm{s}$, and about $19 \%$ saving in cardiac cost of workers per unit of output in comparison to the traditional practice of local sickle was recorded (Singh et al., 2014).

\section{Why mechanized harvesting}

Sickle is the main equipment used for manual harvesting having several issues. Manual harvesting is mainly labor-intensive and timeconsuming operation. Many studies revealed that drudgery is one of the major issues of manual harvest, and mostly women farmers are involved in this operation. In this section, efforts have been made to focus mechanized harvesting of cereals, as timely harvesting not only has larger implications on quality and quantity of harvested produce, but also on sowing and preparedness of the succeeding crops in sequence.

The need for introduction of efficient harvesting equipment for the cereal crops seems to minimize the time of harvesting and the grain loss suffered due to slow rate of work in process of manual harvesting. About $5-15 \%$ loss may occur, if proper care was not taken during harvesting and specifically during manual harvesting (Ojha and Nath, 1980). The various paddy harvesting methods i.e. sickle, power tiller-operated Vertical Conveyor Reaper (VCR) and tractor operated VCR have different costs of operation. It was found that the average harvesting cost was Rs. 520/ha, Rs. 251/ha and Rs. 351.8/ha for sickle, power tiller-operated vertical conveyor reaper and tractor-operated VCR, respectively (Pradhan et al., 1998). In a study on tractorfront mounted reaper-windrower with vertical conveyor belts for harvesting wheat and rice, the unit harvested $0.4 \mathrm{ha} / \mathrm{h}$, and unlike combine, harvester did not destroy the straw, important for cattle fed, and the labor requirement was reduced by two-third as compared to conventional manual harvesting with sickles (Garg and Sharma, 1991). The study conducted on cost-comparison of mechanized harvesting of paddy showed that the actual field capacity of the power reaper was found to be $0.29 \mathrm{ha} / \mathrm{h}$ with a field efficiency of $70 \%$ at an average operating speed of $3 \mathrm{~km} / \mathrm{h}$, with the fuel consumption rate of $0.8 \mathrm{l} / \mathrm{h}$. Thus, the cost of mechanical harvesting was $690 \mathrm{Rs} /$ ha compared to 2,500 $\mathrm{Rs} / \mathrm{ha}$ in traditional method of manual harvesting using local sickle. Hence, the mechanical harvesting would be feasible and economical compared to traditional method in terms of time, labour requirement and money (Murumkar et al., 2014).

The performance of tractor operated combine harvester was evaluated for harvesting of paddy crop. The average value of effective field capacity of the machine was found to be from 0.64 to $0.81 \mathrm{ha} / \mathrm{h}$ with field efficiency of 67 to $77 \%$. The harvesting losses were in the range of 2.9 to $3.6 \%$ during paddy harvesting. The cost of operation was lesser for tractor operated combine harvester as compared to manual method by 57.6 to $65.5 \%$ (Veerangouda et al., 2010).

\section{Improved harvesting technique}

Above two section clearly indicate that farm mechanization is very much essential for harvesting. Different R \& D institutes tried to design different type of manual and powered harvesting equipment for harvesting of paddy and wheat. It can be mainly divided into three categories such as, manual operated harvesting equipment, self-propelled machine and tractor/power tiller-operated machine. The scientists also studied their performance and compared with the traditional method of harvesting. The results of different studies have been revealed for better understanding. 


\section{Manual-operated harvesting equipment}

A manual operated vertical conveyor reaper weighing $45 \mathrm{~kg}$ with $25 \mathrm{~cm}$ effective cutting width was fabricated at a cost of around Rs 4,740 , and its performance was compared with Naveen and local sickle for harvesting paddy crop. Its field capacity and field efficiency were $0.03 \mathrm{ha} / \mathrm{h}$ and $62 \%$ respectively, whereas the average field capacity for Naveen and local sickle was $0.0083 \mathrm{ha} / \mathrm{h}$ and $0.0066 \mathrm{ha} / \mathrm{h}$, respectively. The harvesting cost for developed reaper, Naveen and local sickle were Rs 619/ha, Rs 1500/ha and Rs 1875/ha, respectively (Singh et al., 2009).

The newly developed manual operated reaper was high labor-saving equipment, requiring only $20 \mathrm{man}-\mathrm{h} / \mathrm{ha}$. The field efficiency was satisfactory $(66 \%)$, with much lower cost of harvesting (Rs 1250 /ha) than traditional method (Rs 2000 /ha) (Chavan et al., 2015). Focusing on ease of harvesting operation to the small landholders for harvesting wheat crop, a low-cost machine was designed and fabricated to harvest the crop more efficiently. The machine included handle, main frame, cutter bar, crop divider and lifter, star wheel, ground wheel and supporting wheel. Cutter bar operated directly by ground wheel power. The optimum forward speed of the machine to obtain maximum field capacity was $1.7 \mathrm{~km} / \mathrm{h}$, the effective field capacity of the machine was found to be $0.048 \mathrm{ha} / \mathrm{h}$ and the field efficiency was $71 \%$ (Sinha and Jogdand, 2019).

Fig.1 Labor saving in mechanical method over traditional method of harvesting

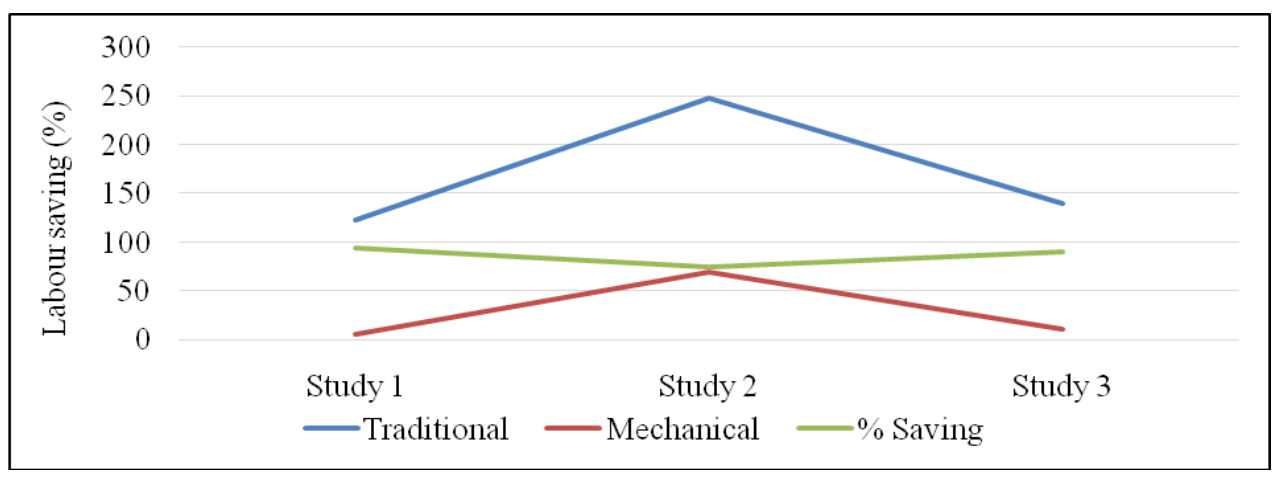

Fig.2 Loss of paddy in harvesting with mechanical method and traditional method

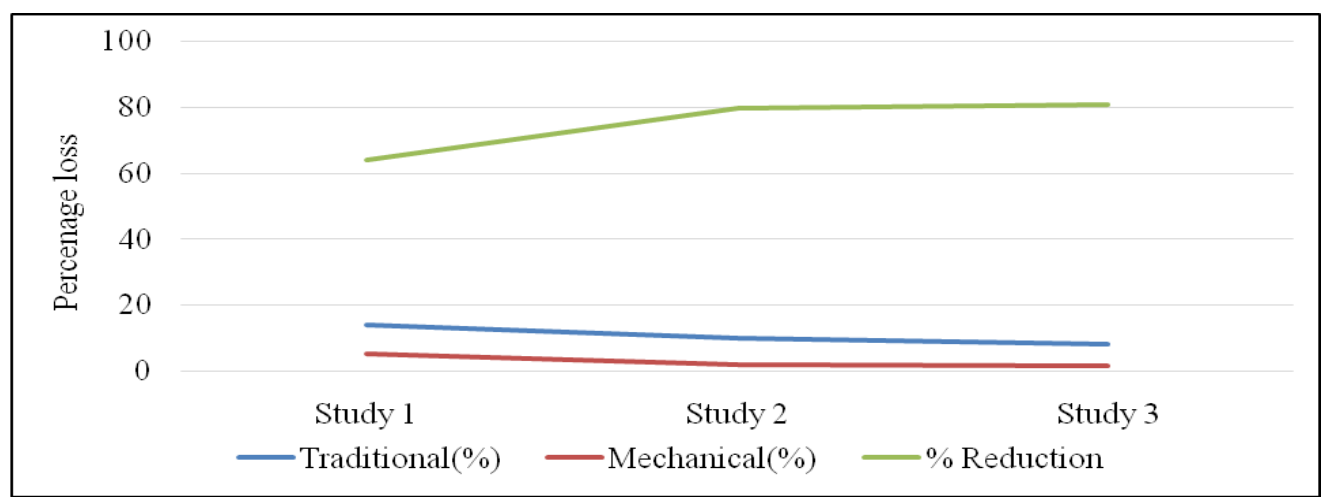


Fig.3 Saving in cost by mechanized paddy harvesting

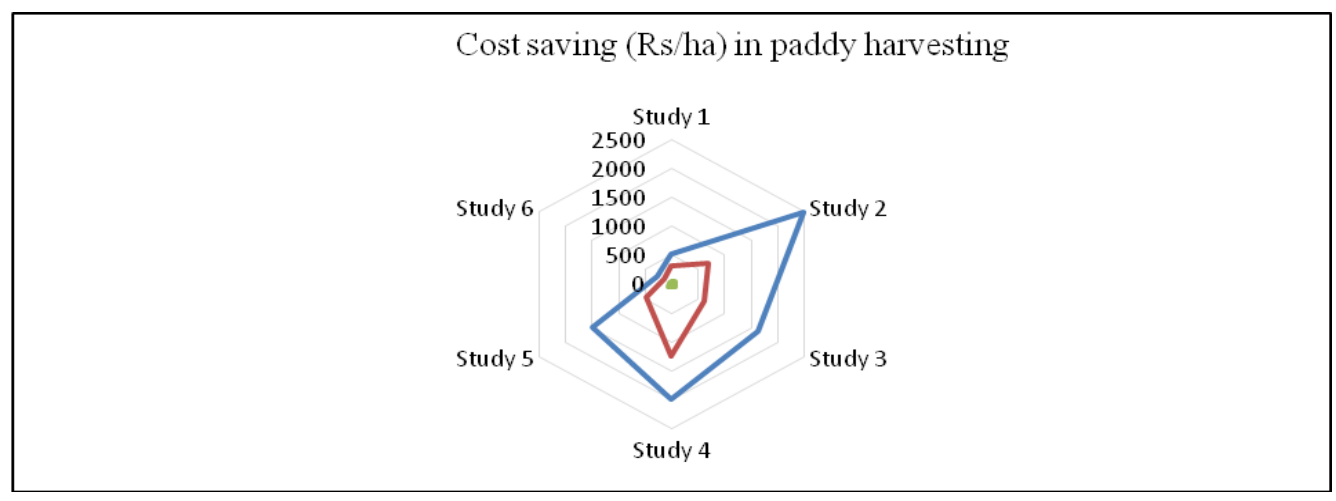

\section{Self-propelled harvesting equipment}

The field performance of a vertical conveyor reaper was evaluated and compared with the conventional method of harvesting. Optimum machine-performance obtained with forward speed was $4.2 \mathrm{~km} / \mathrm{h}$. The harvesting losses increased rapidly as harvesting was delayed which impacted sowing time of succeeding crop(s). The effective field capacity of reaper was $0.43 \mathrm{ha} / \mathrm{h}$ with $3.4 \mathrm{~km} / \mathrm{h}$ forward speed, and $0.47 \mathrm{ha} / \mathrm{h}$ with $4.2 \mathrm{~km} / \mathrm{h}$ forward speed having field efficiency of $76 \%$ and $70 \%$, respectively, whereas manual harvesting has capacity of $0.008 \mathrm{ha} / \mathrm{h}$. Reaping by machine required only $6.5 \mathrm{man}-\mathrm{h} / \mathrm{ha}$ compared to $122.6 \mathrm{man}-\mathrm{h} / \mathrm{ha}$ required for hand reaping. (Amjad and Gee, 1983). The performance of newly developed self-propelled vertical conveyor reaper was compared with the traditional method of harvesting. It was found that the reaper gave $0.2 \mathrm{ha} / \mathrm{h}$ average effective field capacity and $80 \%$ field efficiency with minimum labor requirements of $5 \mathrm{man}-\mathrm{h} / \mathrm{ha}$. The cost of operation was found to be Rs $375 /$ ha which was the lower than traditional (Rs 1125/ha) with a saving of Rs 750 /ha and reduced harvesting losses (2\%) (Gawali, 2005).The actual field capacity of the power reaper was $0.3 \mathrm{ha} / \mathrm{h}$ with a field efficiency of $73 \%$ at an average operating speed of 3.2 $\mathrm{km} / \mathrm{h}$, with the fuel consumption rate $5.5 \mathrm{l} / \mathrm{ha}$.
Cost of mechanical harvesting was Rs.420/ha as compared to Rs $800 /$ ha in manual harvesting (Manjunatha et al., 2009). Evaluation of self-propelled reaper-binder for harvesting of wheat and paddy crop revealed that average forward speed, field capacity, field efficiency and shattering loss was 3.22 $\mathrm{km} / \mathrm{h}, \quad 0.359 \mathrm{ha} / \mathrm{h} 92 \%$ and $0.23 \%$, respectively. The average cost of operations was found to be Rs 1725 /ha(Karahle et al., 2013). The evaluation of performance of selfpropelled riding-type vertical conveyor reaper indicated an average effective field capacity of $0.17 \mathrm{ha} / \mathrm{h}$ at an average forward speed of $1.7 \mathrm{~km} / \mathrm{h}$ with $60 \%$ efficiency. It was found suitable for reaping the crops up to 55 to $60 \mathrm{~cm}$ crop height with an operating cost of Rs 115/h (Mehetre et al., 2014). Aung et al., (2014) compared to manual harvesting by sickle and machine harvesting by power reaper with effective cutting width of $1.2 \mathrm{~m}$, for rice harvesting and revealed that the actual field capacity of the reaper was $0.24 \mathrm{ha} / \mathrm{h}$ compared to $0.05 \mathrm{ha} / \mathrm{h}$ for manual harvesting. Labor requirements for reaper and manual harvesting were 4 and 28 man-h/ha, respectively. The fuel consumption, knife speed, field efficiency and cutting efficiency were $1.89 \mathrm{l} / \mathrm{h}, 1.223 \mathrm{~m} / \mathrm{s}, 92 \%$ and $98 \%$, respectively. The cutting cost of power reaper was $67 \%$ less compared to manual harvesting, and the grain loss was less than $0.5 \%$. 
A newly developed self-propelled reaper was compared with the Chinese reaper and manual harvesting, and their respective field capacity was $0.250 \mathrm{ha} / \mathrm{h}, 0.203 \mathrm{ha} / \mathrm{h}$ and $0.004 \mathrm{ha} / \mathrm{h}$, whereas the corresponding labour requirements (man-h/ha) for rice harvesting including bundle making were 248, 69 and 68 , respectively. Harvesting costs were saved by self-propelled reaper and Chinese reaper by about 68 and $61 \%$, respectively over manual harvesting (Zami et al., 2014).

Another study on the harvesting of wheat and paddy using a self-propelled vertical conveyor reaper revealed that the actual field capacity for paddy harvesting was $0.276 \mathrm{ha} / \mathrm{h}$, whereas for wheat it was found $0.311 \mathrm{ha} / \mathrm{h}$ with fuel consumption $6.12 \mathrm{l} / \mathrm{ha}$ and $5.29 \mathrm{l} / \mathrm{ha}$, respectively. Cost of mechanical harvesting with reaper was found lower by $47.1 \%$ and $44.4 \%$ for paddy and wheat, respectively, in comparison to the manual harvesting (Dangeet al., 2015).

\section{Tractor and power-tiller operated harvesting equipment}

Garg et al., (1985) developed and evaluated field performance of a tractor-front-mounted vertical conveyor-reaper-windrower with 1.9 $m$ cutting width, operated by a tractor of about $25 \mathrm{HP}$, which could effectively harvest wheat and rice and place the harvested crop on the ground in neat windrows that could be easily collected. Its average effective field capacity was $0.29 \mathrm{ha} / \mathrm{h}$, and the total grain losses were only $0.72-1.51 \%$. When compared with traditional manual methods, the machine could save 131 man-h/ha. A tractor-drawn side-mounted reaper was designed to cut the green crops and form crop bunches.

The machine's field efficiency was $66.7 \%$, shattering losses were 2-5\%, and nonrecoverable loose stalk losses were 4.1 and
$3.5 \%$ for 2 varieties at $15 \%$ moisture content. The cost of harvesting soybean crop by this machine was Rs 150/ha as compared to Rs 216/ha for manual harvesting (Yadav, 1985).

A study of a tractor-front-mounted reaperwindrower with vertical conveyor belts for harvesting wheat and rice showed that the unit was capable of harvesting $0.4 \mathrm{ha} / \mathrm{h}$, and unlike combine harvester did not destroy the straw, important for cattle feed. The labor requirement was reduced by two-third withthe new unit as compared to conventional manual harvesting with sickles(Garg and Sharma, 1991). The performance of newly developed power tiller-operated vertical conveyor reaper was evaluated for wheat crop. The average field capacity and fuel consumption were $0.284 \mathrm{ha} / \mathrm{h}$ and $0.5 \mathrm{~L} / \mathrm{h}$, respectively. The total grain losses were very low ( 1\%). Labour savings and financial savings were 129 manh/ha and Rs 226/ha with machine harvesting compared to the traditional method (Garg et al., 1984).

In conclusion based on the review and analysis of foregoing studies at different locations it may be concluded that the performance of power-operated reapers is better than manual harvesting method. The evidence of the studies showed that $85 \%$ of labour saving and approximately $75 \%$ reduction in harvesting losses are two major benefits of mechanized harvesting method. The reduction in cost of harvesting of paddy per hectare was found 55\% (Fig 1,2,3). Moreover, saving in operational time helps early clearance of the field making way for early/ timely sowing of succeeding crop, leading to increase in cropping intensity as well as system productivity. It implies that self-propelled reaper, and tractor/power-tiller operated reapers (mechanized harvester) are better alternative options for harvesting of cereal crops. 


\section{References}

Amjad, N. and Gee-Clough, D. (1983). Field performance evaluation of rice reaper. AMA. 14(4): 18-21.

Aung, N.N.; Myo, P.P. and Moe, H.Z. (2014). Field performance evaluation of a power reaper for rice Harvesting. International Journal of Scientific Engineering and Technology Research. 12(3): 2631-2636.

Chavan, P.B.; Patil, D.K., and Dhondge, D.S. (2015). Design and development of manually operated reaper. IOSR Journal of Mechanical and Civil Engineering. 12(3): 15-22.

Dange, A.R.; Sahu, B.; Nayak, R.K. and Salam, D. (2015). Mechanization of harvesting operation of rice and wheat in Uttar BastarKanker district of Chhattisgarh state. Journal of Agriculture, Forestry and Environmental Science. 1(2):58-59.

Devnani, R.S. and Pandey, M.M. (1981). Harvesting hand tools of India. Tech. Bull. No. CIAE/81/25 Central Institute of Agricultural engineering, Bhopal, India: 19-20.

Garg, I.K.; Sharma, V.K. and Singh, S. (1984). A power tiller-operated verticalconveyer reaper windrower. AMA 15(3):40-44.

Garg, I.K.; Sharma, V.K. and Gupta, P.K. (1985). Design, development and field evaluation of a tractor-front-mounted vertical conveyor-reaper-windrower. Indian Journal of Agricultural Sciences. 55(8): 543-547.

Garg, I.K. and Sharma, V.K. (1991). Tractoroperated vertical-conveyer reaper windrower. Indian Farming. 40(11):3236.

Gawali, S. G. (2005). Development and testing of low cost self-propelled vertical conveyor reaper. Unpublished, M-Tech. thesis, Indira Gandhi
Agricultural University, Raipur.

Gite, L.P., Agarwal, N. (2000). Ergonomically comparison of local and improved sickles for wheat harvesting by women workers. Agriculture Engineering Today, 24(3):7-12.

Karahle, S.S.; Gajakos, A.V.; Neharkar, P.S.; Kamdi, S.R. and Lambe, S.P. (2013).Performance evaluation of selfpropelled reaper binder. IJAAS. 2(1): 47-5.

Manjunatha, M.V.; Masthana, B.G.; Shashidhar, S.D. and Joshi, V.R. (2009). Field performance evaluation of vertical conveyor paddy reaper. Karnataka Journal of Agricultural Sciences. 22(1): 140-142.

Mehetre, S.A.; Ghatge, J.S. and Bandgar, P.S. (2014). Performance evaluation of selfpropelled riding type vertical conveyor reaper. International Journal of Agricultural Engineering. 7(1):38-41.

Murumkar, R. P., Dongarwar, U. R., Borkar, P. A., Pisalkar, P. S., \&Phad, D. S. (2014). Performance evaluation of selfpropelled vertical conveyor reaper. International Journal of Science, Environment and Technology, 3(5), 1701-1705.

Nadeem Amjad, 1983. Field performance evaluation of rice reaper. In: Agricultural mechanization in Asia, Africa and Latin America, 14:35-40.

Ojha, T. P., \& Nath, S. (1980). Studies on harvesting of crop minimizing harvest and post-harvest losses. Bulletin on harvest and post-harvest technology (ICAR) Scheme. IIT Kharagpur, 4-9.

Pradhan, S.C.; Das, D.K.; Mahapatra, M. and Ray, B. (1998). Evaluation of various paddies harvesting method in Orissa, India. AMA. 29(2): 35-38.

PwC 2019. Farm mechanisation: Ensuring a sustainable rise in farm productivity and income. Pp1-53

Singh, M.S. and Singh, K.N. (1978). Force 
requirement of different sickles. Journal of Agricultural Engineering (ISAE) 15: 11-18.

Singh, R.; Khakha, J. and Singh, G. (2009). Development and testing of manually operated vertical conveyor reaper. Unpublished, B-Tech. thesis, Indira Gandhi Agricultural University, Raipur.

Singh, S.P. (2012). Physiological workload of farm women while evaluating sickles for paddy harvesting. Agric Eng. Int: CIGR Journal. 14 (1): 1540

Singh, A., Gautam, U. S., Singh, R., \&Paliwal, D. (2014). Ergonomic study of farm women during wheat harvesting by improved sickle. African Journal of agricultural research, 9(18), 13861390.

Sinha, P., \&Jogdand, S. V. (2019). Design and development of manually operated harvester for wheat crop. Journal of Pharmacognosy and Phytochemistry, 8(6), 543-545.

Veerangouda, M.; Sushilendra, K.V. and Anantachar, M. (2010). Performance evaluation of tractor operated combine harvester. Karnataka Journal. Agricultural. Sciences. 23 (2):282-285.

Verma, S.; Gupta, S. and Pachauri, C.P. (2016). Superiority of the Naveen serrated sickle over the traditional sickle for wheat harvesting. International Journal of Farm Sciences. 6(1): 214222.

Yadav, R.N.S. and Yadav, B.G. (1985). Design and development of a tractor drown soybean reaper. ISAE proceeding of the silver jubilee's convention held in Bhopal, India, 29-31. Vol.1. Farm machinery and power. 1985, 11-88, 11-92.

Zami, M.A.; Biswas, B.K. and Hossain, M.A. (2014). Performance evaluation of the BRRI reaper and Chinese reaper compared to manual harvesting of rice. A Scientific Journal of Krishi Foundation. 12(2):142-150.

http://www.fao.org/faostat/en/\#data/QC

\section{How to cite this article:}

Suryakanta Khandai, Nitesh Gupta, Saurajyoti Baishya, Kanwar Singh and Virendar Kumar. 2021. Opportunity of Mechanized Harvesting Methods of Cereal Crops in India: A Review. Int.J.Curr.Microbiol.App.Sci. 10(01): 3137-3145. doi: https://doi.org/10.20546/ijcmas.2021.1001.365 